\title{
Herd-level spatial cluster analysis of bovine cysticercosis in the state of Paraíba, northeastern Brazil
}

\author{
Análise de aglomerados espaciais no nível do rebanho de cisticercose bovina no Estado da Paraíba, \\ Nordeste do Brasil \\ Amanda Rafaela Alves Maia ${ }^{1}$; Paulo Sérgio de Arruda Pinto ${ }^{2}$; Rafaella Paola Meneguete dos Guimarães Peixoto ${ }^{2}$; \\ Letícia Ferreira da Silva ${ }^{2}$; Leise Gomes Fernandes ${ }^{1}$; Carolina de Sousa Américo Batista Santos ${ }^{3}$; Clebert José Alves ${ }^{1}$; \\ Sérgio Santos de Azevedo ${ }^{1 *}$

\begin{abstract}
${ }^{1}$ Programa de Pós-graduação em Medicina Veterinária, Universidade Federal de Campina Grande - UFCG, Patos, PB, Brasil
${ }^{2}$ Departamento de Medicina Veterinária, Universidade Federal de Viçosa - UFV, Viçosa, MG, Brasil

${ }^{3}$ Departamento de Medicina Veterinária, Universidade Federal da Paraíba - UFPB, Areia, PB, Brasil
\end{abstract}

Received September 18, 2016

Accepted December 19, 2016

\begin{abstract}
The aim of this survey was to identify spatial clustering of bovine cysticercosis-positive herds in the state of Paraíba. The state was divided into three sampling groups: sampling stratum 1 (Sertáo mesoregion), sampling stratum 2 (Borborema mesoregion) and sampling stratum 3 (Zona da Mata and Agreste mesoregions), and 2382 cows aging $\geq 24$ months from 474 farms were sampled. Serological diagnoses of bovine cysticercosis were initially done by means of indirect ELISA, and positive serum samples were confirmed by a immunoblot test. Herds were deemed positive for cysticercosis if they presented at least one positive animal in herds of up to 29 females, and two positive animals in herds with more than 29 females. The spatial clustering was assessed using the Cuzick-Edwards $k$-nearest neighbor method and spatial scan statistics. A significant clustering of positive herds was detected in the southern part of the Borborema mesoregion. Given that serological tests for bovine cysticercosis are not widely available, and also that replacement and maintenance of herds through animal purchases is common in the region, it can be concluded that prevention measures should be applied at herd level.
\end{abstract}

Keywords: Cattle, epidemiology, cluster analysis, bovine cysticercosis.

\section{Resumo}

O objetivo deste estudo foi identificar agrupamentos espaciais de rebanhos positivos para cisticercose bovina no Estado da Paraíba. O Estado foi dividido em três grupos amostrais: estrato amostral 1 (mesorregião do Sertão), estrato amostral 2 (mesorregião da Borborema), e estrato amostral 3 (mesorregióes da Zona da Mata e Agreste), e 2.382 vacas com idade $\geq 24$ meses foram amostradas a partir de 474 propriedades. O diagnóstico sorológico da cisticercose bovina foi, inicialmente, realizado pelo ELISA indireto, e as amostras de soro positivas foram confirmadas por immunoblot. Um rebanho foi considerado positivo para cisticercose, se apresentasse pelo menos um animal positivo em rebanhos de até 29 fêmeas; e dois animais positivos em rebanhos com mais de 29 fêmeas. Os agrupamentos espaciais foram avaliados com o uso da metodologia $k$-vizinhos mais próximos de Cuzick-Edwards e estatística espacial de varredura. Um agrupamento significativo de rebanhos positivos foi detectado na parte sul da mesorregião da Borborema. Tendo em vista que os testes sorológicos para diagnóstico de cisticercose bovina não são amplamente disponíveis, bem como é comum na região a reposiçáo e manutenção dos rebanhos por compra de animais, conclui-se que medidas de prevenção devem ser aplicadas em nível de rebanho.

Palavras-chave: Gado, epidemiologia, análise de cluster, cisticercose bovina.

\footnotetext{
*Corresponding author: Sérgio Santos de Azevedo. Laboratório de 


\section{Introduction}

Bovine cysticercosis is a tropical zoonotic disease caused by the larval stage of Taenia saginata in cattle. Its adult phase causes taeniasis in humans (CALVO-ARTAVIA et al., 2013). Cattle become infected by consuming contaminated water or by feeding on pasture containing viable eggs of the parasite or through any other manner that leads to intake of these eggs. Despite the limitations, postmortem inspection has been used as a control measure and it indicates the degree of bovine cysticercosis infection. Therefore, visual inspection of beef carcasses during slaughter is very important for reducing the risk for consumers (COSTA et al., 2012), since this zoonosis has great public health importance in developing countries and causes economic losses to the beef supply chain (LARANJO-GONZÁLEZ et al., 2016).

Data on bovine cysticercosis in Brazil is available only from veterinary inspection records at slaughterhouses, and some cases may be unnoticed, especially in mild infections. Thus, the use of serological tests with sensitivity higher than the routine postmortem inspection has been recommended as an option for antemortem detection of bovine cysticercosis, allowing a more accurate early identification of infected animals (PAULAN et al., 2013; GUIMARÁES-PEIXOTO et al., 2015). Positive findings for bovine cysticercosis based on absolute numbers of occurrences may lead to misinterpretation of the disease spatial distribution, since regions with high concentrations of these events are not always the areas with the highest risk (BAVIA et al., 2012). Therefore, epidemiological maps of disease risk have been produced in order to correlate disease data with environmental features at sites known to harbor bovine cysticercosis. However, studies on the distribution of bovine cysticercosis in Brazil have only taken postmortem inspections into account and not serological tests (BAVIA et al., 2012; DUTRA et al 2012; ROSSI et al., 2016). Thus, so far, no surveys involving herd-level spatial clustering analysis on bovine cysticercosis seroprevalence in Brazil have been conducted.

Spatial clustering analysis is a useful tool for studying the spread of infectious diseases in animal populations. The identification of clusters might yield important information about the transmission and/or control measures for such diseases (CARPENTER, 2001). Thus, in the present study, a spatial cluster analysis was performed with the aim of determining the spatial distribution of bovine cysticercosis in the state of Paraíba, northeastern Brazil.

\section{Materials and Methods}

\section{Sampling}

The data used in the present study originated from an epidemiological survey for bovine cysticercosis in the state of Paraíba (MAIA, 2016). The state of Paraíba was divided into three sampling groups: sampling stratum 1 (Sertão mesoregion), sampling stratum 2 (Borborema mesoregion), and sampling stratum 3 (Zona da Mata and Agreste mesoregions) (Figure 1). For each sampling stratum, a pre-established number of herds were randomly selected (primary sampling units) and then, a pre-established number of cows aged $\geq 24$ months were randomly selected (secondary sampling units).
The number of herds selected per sampling stratum was determined by simple random samples (THRUSFIELD, 2007) adopting 95\% confidence level, 1.1\% estimated herd-level prevalence (SANTOS et al., 2013) and 5\% error. Nevertheless the veterinarians and agricultural and livestock technicians of the Secretariat of Agricultural and Fisheries Development of the State of Paraíba (SEDAP) were involved in the fieldwork, so the operational and financial capacity of the SEDAP was taken into consideration and herd sample size was adjusted to their field capacity. For the secondary units, the minimum number of animals to be examined within each herd in order to allow it to be classified as positive was estimated using the concept of aggregate sensitivity and specificity (DOHOO et al., 2003), considering 81.25\% (SILVA et al., 2015a) and 98.3\% (SILVA et al., 2015b) for the sensitivity and specificity, respectively, for indirect ELISA and immunoblot tests serially applied and $31 \%$ for the intra-herd estimated prevalence (ASAAVA et al., 2009). The Herdacc version 3 software (JORDAN, 1995) was used during this process, and the sample size was selected so that the herd sensitivity and specificity values would be $\geq 90 \%$. Therefore, 10 animals were sampled in herds with up to 99 cows aging over 24 months; 15 animals were sampled in herds with 100 or more cows aging over 24 months; and all animals were sampled in those with up to 10 cows aging over 24 months. Cows within the herds were selected systematically. In total, 2382 animals in 474 cattle herds were sampled.

The target condition was a seropositive animal within an infected herd. The herd-level case definition was based on the size of the population (cows aging $\geq 24$ months), number of females sampled, an intra-herd apparent prevalence of 31\% (ASAAVA et al., 2009), and the sensitivity and specificity of the diagnostic tests that were used serially (indirect ELISA and immunoblot), with the goal of achieving herd sensitivity and specificity of $\geq 90 \%$. After new simulations using the Herdacc software, a herd was deemed positive for cysticercosis if it included at least one positive animal in herds of up to 29 females, and two positive animals in herds with more than 29 females.

\section{Serological diagnosis}

The serological diagnosis of bovine cysticercosis was initially done by using indirect ELISA and positive serum samples were confirmed by the immunoblot test. Both tests were carried out in accordance with methodologies previously described by Pinto et al. (2000) and Silva et al. (2015a, b), using T. crassiceps larvae as antigens. For indirect ELISA, the positivity and negativity of each sample was determined by calculating the cut-off points which were defined as the mean of the optical densities (OD) of the reactions of the negative control serum samples, plus two standard deviations.

\section{Statistical analysis}

The spatial clustering of bovine cysticercosis-positive herds was assessed using two methods (WARD \& CARPENTER, 2000). First, the Cuzick-Edwards $k$-nearest neighbor method (CUZICK \& EDWARDS, 1990) was used to detect the possibility of global spatial clustering at herd level using the ClusterSeer 2.5.1 software 
(BioMedware, Ann Arbor, MI, United States). The existence of potential spatial clustering was analyzed at each of the first 10 neighborhood levels, and the overall p-value was adjusted for multiple comparisons using the Simes approach. Furthermore, scan statistics generated through the SatScan software version 9.0 (KULLDORFF \& NAGARWALLA, 1995) were used to identify local clusters of positive herds. A Bernoulli model was applied, the scanning window was circular and the spatial size of the scan window was limited to $25 \%$ of the total population.

\section{Results and Discussion}

The herd-level prevalence in the state of Paraíba was $10.8 \%$ $(95 \% \mathrm{CI}=8.1 \%-14.1 \%), 10.3 \%(95 \% \mathrm{CI}=6.4 \%-16.1 \%)$ in the Sertão region, $6.9 \%(95 \% \mathrm{CI}=3.9 \%-12.1 \%)$ in the Borborema region and $13.8 \%(95 \% \mathrm{CI}=9.3 \%-20.2 \%)$ in the Agreste and Zona da Mata regions (Table 1). The herd-level prevalence found in the State of Paraíba, especially in the Agreste/Zona da Mata and Sertão mesoregions, where herd-level prevalences were $13.8 \%$ (95\% CI $=9.3 \%-20.2 \%)$ and $10.3 \%$ (95\% CI $=6.4 \%-16.1 \%)$, respectively, indicate that bovine cysticercosis is spread in cattle herds in the region. Data on bovine cysticercosis prevalence using serological methods as diagnostic tests in Brazil are scarce and limited to local surveys. Seropositivities rates at animal level have been referred to range from $0.4 \%$ to $4.1 \%$ in surveys conducted in the state of Minas Gerais (IASBIK et al., 2010; ACEVEDO et al. 2012; SANTOS et al., 2013; FELIPPE et al., 2014; GARRO et al., 2015). It seems that the herd-level prevalence could be even higher in Paraíba, once for this study only cows aged $\geq 24$ months were

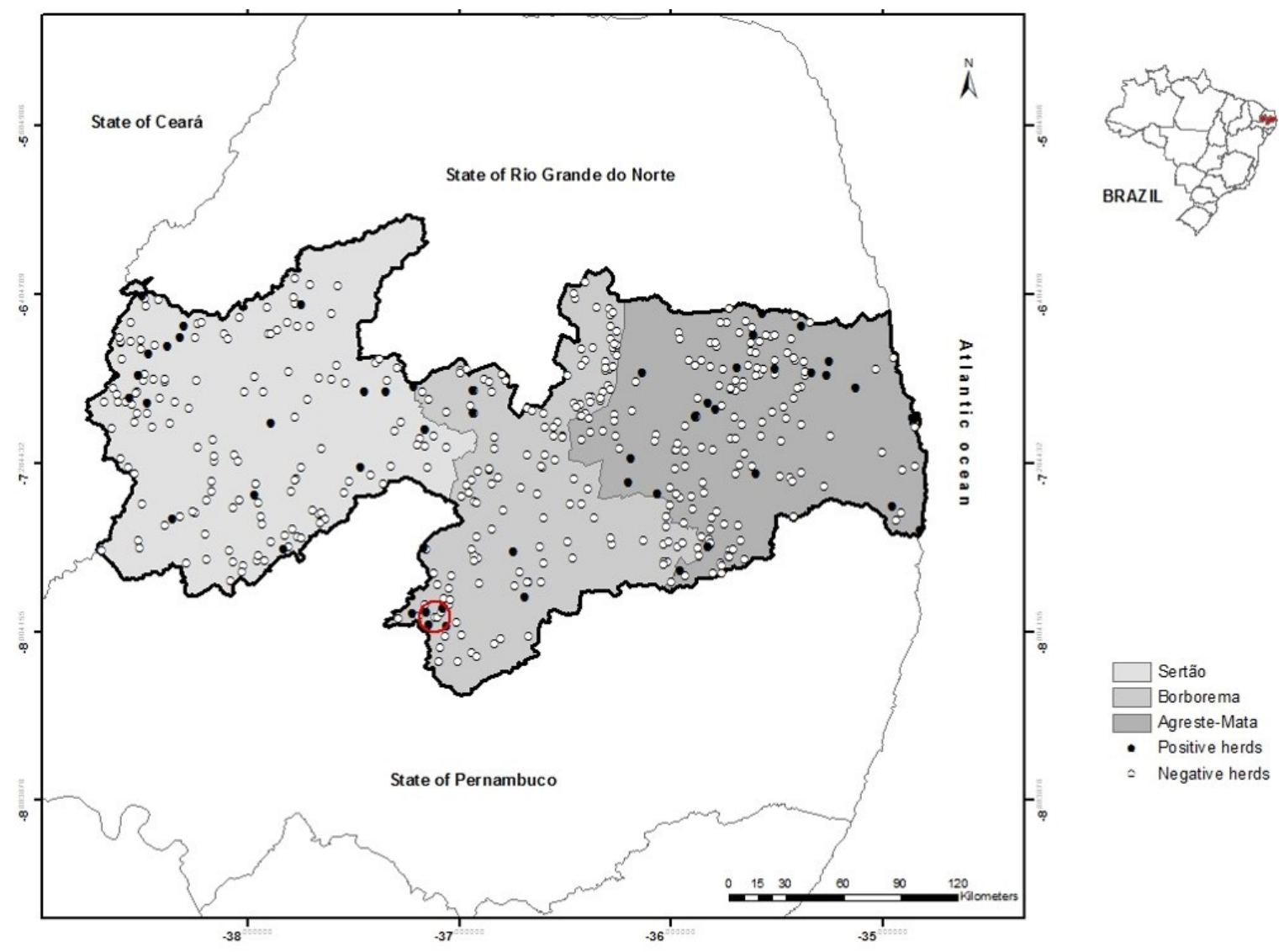

Figure 1. Significant cluster (red line) of bovine cysticercosis positive herds in the State of Paraíba. Detail shows Paraíba State within Brazil.

Table 1. Census data on the cattle population according to sampling stratum and herd-level prevalence of bovine cysticercosis, in the state of Paraíba, northeastern Brazil.

\begin{tabular}{|c|c|c|c|c|c|}
\hline \multirow{2}{*}{ Sampling stratum } & \multirow{2}{*}{ Total no. of herds } & \multicolumn{2}{|c|}{ No. of herds } & \multirow{2}{*}{ Prevalence (\%) } & \multirow{2}{*}{$95 \%$ CI } \\
\hline & & Tested & Positive & & \\
\hline Sertão & 24,356 & 156 & 16 & 10.3 & {$[6.4-16.1]$} \\
\hline Borborema & 11,603 & 159 & 11 & 6.9 & {$[3.9-12.1]$} \\
\hline Agreste/Zona da Mata & 18,398 & 159 & 22 & 13.8 & {$[9.3-20.2]$} \\
\hline State of Paraíba & 54,357 & 474 & 49 & 10.8 & [8.1-14.1] \\
\hline
\end{tabular}


used. Nevertheless, within-herd prevalence ranged from $7.1 \%$ to $100 \%$ (median of $16.7 \%$ ).

No significant clusters were identified (Simes $\mathrm{p}>0.05$ ) through the Cuzick and Edwards method for the entire state of Paraiba. However, when the state was divided into separate strata, significant global clustering (Simes $\mathrm{p}<0.05$ ) of positive herds was detected through the Cuzick and Edwards method at the $k=3$ neighborhood level in the Borborema mesoregion. Using the Bernoulli model, a spatial cluster of positive herds was detected in the southern part of the Borborema mesoregion (Figure 1). In this cluster, the number of herds was 7 , the radius of the cluster was $8.02 \mathrm{~km}$ and the numbers of observed and expected cases (positive herds) were 5 and 0.53 , respectively, such that the risk of infection was 15.4 (relative risk $=15.4 ; \mathrm{p}=0.008$ ) times higher in herds located inside the cluster than in those located elsewhere. Allepuz et al. (2009) identified two statistically significant clusters of bovine cysticercosis in the Catalonia region (northeastern Spain) and concluded that the location of the farm may also have an influence on the risk of bovine cysticercosis. These authors suggested that the large number of infected animals and the fact that the animals originated from different regions in Spain and different countries in Europe, practically ruled out the possibility of that the animals had become infected at their origin.

In the present study, there was a lack of spatial clustering of bovine cysticercosis throughout the state of Paraíba, but a spatial cluster was identified considering each mesoregion independently. However, it can be inferred that this cluster cannot be explained by spatially structured factors as reported by Ávila et al. (2013), who detected clustering for bovine tuberculosis in the state of Bahia only when the regions were analyzed separately. The geographical divisions (Sertão, Borborema and Agreste/Zona da Mata) that were created in the present study for analysis purposes were not subject to the real parameters regarding occurrences of cysticercosis and did not respect geographical boundaries. Thus, the cluster found in the Borborema region can be explained by its location at the border with the State of Pernambuco. More precisely, it is close to the place where there is the second largest cattle fair in the state, in the municipality of Tabira. Large-scale movements of animals from different locations occur at this fair, which may result in greater numbers of traded animals that may have cysticercosis.

In the state of Paraiba, most farms are family-run or subsistence farms, with predominantly mixed production and semi-intensive farming (CLEMENTINO et al., 2015). This leads to inappropriate practices such as self-consumption of the farm's meat or selling it within the community, without any sanitary inspection (ARAGÃO et al., 2010). Thus, the cattle may be exposed to important environmental risk factors for bovine cysticercosis, such as surface water, flooded pastures and grazing on pastures contaminated with T. saginata eggs from human feces, which favors persistence of the taeniasis-cysticercosis complex (BARBOSA et al., 2001; BOONE et al., 2007).

Detection of spatial clustering involves complex methodology and has limitations but it can bring more accurate results and help decision-making, for greater efficiency of sanitary measures as pointed out by Ávila et al. (2013). In the present context, it is not plausible to suggest testing cows prior to purchasing them because serological tests for bovine cysticercosis are costly, not widely available, and do not differentiate between previous and active infection. Moreover, replacement or maintenance of livestock by animal purchases is common in the region. Therefore, measures should be based on disease prevention at herd level, such as avoidance of contact with human feces and contaminated water and food, among cattle (MURRELL et al., 2005).

Taking into account the multiplicity of factors that is involved in the transmission of bovine cysticercosis (BAVIA et al., 2012), and the high prevalence of bovine cysticercosis in the state of Paraiba further epidemiological surveys should be conducted among both humans and cattle, with the aim of identifying possible conditions that could act as risk factors for the occurrence and distribution of bovine cysticercosis in this region.

\section{Acknowledgements}

This study was financed by the National Council for Scientific and Technological Development (Conselho Nacional de Desenvolvimento Científico e Tecnológico, CNPq), under the codes 471571/2011-3, 302131/2012-4 and 476596/2013-0.

\section{References}

Acevedo EC No, Ferreira PS, Santos TO, Guimarães Peixoto RPM, Silva LF, Fellipe AG, et al. Prevalence of teniasis-cysticercosis complex in a rural area of Matias Barbosa-MG. Semina: Ciênc Agrár 2012; 33(6): 2307-2314.

Allepuz A, Napp S, Picado A, Alba A, Panades J, Domingo M, et al. Descriptive and spatial epidemiology of bovine cysticercosis in North-Eastern Spain (Catalonia). Vet Parasitol 2009; 159(1): 43-48. PMid:19027236. http://dx.doi.org/10.1016/j.vetpar.2008.09.027.

Aragão SC, Biondi GF, Lima LG, Nunes CM. Animal cysticercosis in indigenous Brazilian villages. Rev Bras Parasitol Vet 2010; 19(2): 132-134. PMid:20624354. http://dx.doi.org/10.4322/rbpv.01902014.

Asaava LL, Kitala FM, Gathura PB, Nanyingi MO, Muchemi G, Schelling E. A survey of bovine cysticercosis/human taeniosis in Northen Turkana District, Kenya. Prev Vet Med 2009; 89(3-4): 197-204. PMid:19329200. http://dx.doi.org/10.1016/j.prevetmed.2009.02.010.

Ávila LN, Perez AM, Ferreira JS No, Ferreira F, Telles EO, Dias RA, et al. Análise de detecçáo de cluster na caracterizaçáo espaço-temporal da tuberculose bovina no Estado da Bahia. Pesq Vet Bras 2013; 33(11): 1313-1318. http://dx.doi.org/10.1590/S0100-736X2013001100005.

Barbosa OF, Rocha UF, Costa AJ, Silva GS, Soares VE, Soccol VT, et al. Assessment of sewage water as carrier of pathogenic organisms to cattle. Semina: Ciênc Agrár 2001; 22(1): 27-37.

Bavia ME, Carneiro DDMT, Cardim LL, Silva MMN, Martins MS. Estatística espacial de varredura na detecção de áreas de risco para a cisticercose bovina no estado da Bahia. Arq Bras Med Vet Zootec 2012; 64(5): 1200-1208. http://dx.doi.org/10.1590/S0102-09352012000500018.

Boone I, Thys E, Marcotty T, Borchgrave J, Ducheyne E, Dorny P. Distribution and risk factors of bovine cysticercosis in Belgian dairy and mixed herds. Prev Vet Med 2007; 82(1-2): 1-11. PMid:17559956. http://dx.doi.org/10.1016/j.prevetmed.2007.05.002.

Calvo-Artavia FF, Nielsen LR, Alban L. Epidemiologic and economic evaluation of risk-based meat inspection for bovine cysticercosis in Danish 
cattle. Prev Vet Med 2013; 108(4): 253-261. PMid:23182031. http:// dx.doi.org/10.1016/j.prevetmed.2012.11.002.

Carpenter TE. Methods to investigate spatial and temporal clustering in veterinary epidemiology. Prev Vet Med 2001; 48(4): 303-320. PMid:11259822. http://dx.doi.org/10.1016/S0167-5877(00)00199-9.

Clementino IJ, Pimenta CLRM, Fernandes LG, Bezerra CS, Alves CJ, Dias RA, et al. Characterization of cattle raising in Paraíba State, Northeastern Brazil. Semina: Ciênc Agrár 2015; 36(1): 557-570.

Costa RFR, Santos IF, Santana AP, Tortelly R, Nascimento ER, Fukuda RT, et al. Caracterização das lesões por Cysticercus bovis, na inspeção post mortem de bovinos, pelos exames macroscópico, histopatológico e pela reação em cadeia da polimerase (PCR). Pesq Vet Bras 2012; 32(6): 477 484. http://dx.doi.org/10.1590/S0100-736X2012000600002.

Cuzick J, Edwards R. Spatial clustering for inhomogeneous populations. JR Stat Soc, B 1990; 52(1): 73-104.

Dohoo IR, Martin W, Stryhn H. Veterinary epidemiologic research. Charlottetown: Atlantic Veterinary College; 2003.

Dutra LH, Girotto A, Vieira RFC, Vieira TSWJ, Zangirolamo AF, Marquês FAC, et al. The prevalence and spatial epidemiology of cysticercosis in slaughtered cattle from Brazil. Semina: Ciênc Agrár 2012; 33(5): 1887-1896.

Felippe AG, Pinto PSA, Santos TO, Acevedo EC No, Guimarães Peixoto RPM, Silva LF. Características favoráveis ao controle do complexo teníasecisticercose em uma regiáo rural de Minas Gerais, Brasil. Rev Bras Ciênc Vet 2014; 21(4): 243-246.

Garro FL, Santos TM, Assis DCS, Heneine LGD, Ornellas CBD, Pinto PSA, et al. Diagnóstico do complexo teníase-cisticercose bovina em São João Evangelista, Minas Gerais, Brasil. Arq Bras Med Vet Zootec 2015; 67(4): 1063-1069. http://dx.doi.org/10.1590/1678-4162-8196.

Guimarães-Peixoto RPM, Pinto PSA, Nero LA, Santos TO, Silva LF, Acevedo EC No, et al. Desempenho do ELISA no diagnóstico da cisticercose utilizando bovinos experimentalmente e naturalmente infectados com o metacestódeo de Taenia saginata. Semina: Ciênc Agrár 2015; 36(2): 807-816.

Iasbik AF, Pinto PSA, Bevilacqua PD, Nero LA, Santos TO, Felippe AG. Prevalência do complexo teníase-cisticercose na zona rural do município de Viçosa, Minas Gerais. Ciênc Rural 2010; 40(7): 1664-1667. http:// dx.doi.org/10.1590/S0103-84782010005000105.

Jordan D. Herdacc: a program for calculating herd level (aggregate) sensitivity and specificity. Guelph: University of Guelph; 1995.

Kulldorff M, Nagarwalla N. Spatial disease clusters: detection and inference. Stat Med 1995; 14(8): 799-810. PMid:7644860. http://dx.doi. org/10.1002/sim.4780140809.
Laranjo-González M, Devleesschauwer B, Gabriël S, Dorny P, Allepuz A. Epidemiology, impact and control of bovine cysticercosis in Europe: a systematic review. Parasit Vectors 2016; 9(1): 81. PMid:26860313. http://dx.doi.org/10.1186/s13071-016-1362-3.

Maia ARA. Epidemiological and spatial characterization of bovine cysticercosis in Paraíba State, Northeastern Brazil [Dissertation]. Patos: Universidade Federal de Campina Grande; 2016.

Murrell KD, Dorny P, Flisser A, Geerts S, Kyvsgaard NC, McManus D, et al. WHO/FAO/OIE Guidelines for the surveillance, prevention and control of taeniosis/cysticercosis [online]. 2005 [cited 2016 Jul 22]. Available from: http://apps.who.int/iris/bitstream/10665/43291/1/9290446560_eng.pdf

Paulan SC, Gonzáles RM, Peralta LA, Vicentini-Oliveira JC, Biondi GF, Conde ES, et al. Usefulness of serological ELISA assay for Taenia saginata to detect naturally infected bovines. Rev Bras Parasitol Vet 2013; 22(2): 270-275. PMid:23802239. http://dx.doi.org/10.1590/S198429612013005000026.

Pinto PSA, Vaz AJ, Germano PLM, Nakamura PM. Performance of the ELISA test for swine cysticercosis using antigens of Taenia solium and Taenia crassiceps cysticerci. Vet Parasitol 2000; 88(1-2): 127-130. PMid:10681029. http://dx.doi.org/10.1016/S0304-4017(99)00201-0.

Rossi GA, Simoni HA, Lopes WD, Almeida HM, Soares VE, Vidal AM, et al. Prevalence and geospatial distribution of bovine cysticercosis in the state of Mato Grosso, Brazil. Prev Vet Med 2016; 130: 94-98. PMid:27435651. http://dx.doi.org/10.1016/j.prevetmed.2016.06.008.

Santos TO, Pinto PSA, Iasbik AF, Silva LF, Acevedo EC No, Guimarães Peixoto RPM. Epidemiological survey of the taeniasis/cysticercosis complex in cattle farms in Viçosa County, Minas Gerais, Brazil. Pesq Vet Bras 2013 33(4): 449-452. http://dx.doi.org/10.1590/S0100-736X2013000400006.

Silva LF, Pinto PSA, Duarte CTD, Santos TO, Acevedo EC No, Guimarães Peixoto RPM. Applicability of ELISA with different antigens to diagnose varying levels bovine cysticercosis. Semina: Ciênc Agrár 2015a; 36(3): 2013-2022.

Silva LF, Pinto PSA, Ducas CTS, Santos TO, Acevedo EC No, Guimarães Peixoto RPM. Relevant peptides of Taenia crassiceps for the diagnosis of bovine cysticercosis by immunoblot. Arq Bras Med Vet Zootec 2015b; 67(3): 891-898. http://dx.doi.org/10.1590/1678-4162-7291.

Thrusfield M. Veterinary epidemiology. 3rd ed. Oxford: Blackwell Science; 2007.

Ward MP, Carpenter TE. Techniques for analysis of disease clustering in space and in time in veterinary epidemiology. Prev Vet Med 2000; 45(3-4): 257-284. PMid:10821965. http://dx.doi.org/10.1016/S01675877(00)00133-1. 